\title{
Effect of GM-CSF on Porcine Parthenotes Development
}

\author{
Jae-Dal Lee i* $^{*}$ \\ ${ }^{1}$ Department of Pet Care, Hyejeon College \\ GM-CSF가 돼지 처녀 생식 배아 발달에 미치는 영향 \\ 이재달 ${ }^{*}$ \\ ${ }^{1}$ 혜전대학교 애완동물관리과
}

\begin{abstract}
Granulocyte-macrophage colony-stimulating factor (GM-CSF) is an important hematopoietic growth factor and immune modulator. The aim of this study was to evaluate the effects of GM-CSF on the development and cell number of porcine parthenotes, as well as on their expression of implantation-related genes. In the present study, porcine parthenogenatic activated embryos were cultured in a protein-free culture medium in the absence or presence of 5, 10 and $20 \mathrm{ng} / \mathrm{ml} \mathrm{GM-CSF}$ for 7 days. The percentage of blastocyst formation, total cell number and gene expressions were evaluated. The results showed that the addition of $20 \mathrm{ng} / \mathrm{ml}$ GM-CSF to protein-free culture medium significantly increased the blastocoel formation $(26.14 \pm 2.03 \%$ vs. $3.55 \pm 0.51 \%, p<0.05)$. In addition, the cell number also increased when they were cultured in the presence of $20 \mathrm{ng} / \mathrm{ml}$ GM-CSF $(43.51 \pm 3.6 \%$ vs. $30.68 \pm$ $5.51 \%, \mathrm{p}<0.05$ ). A real time reverse transcripts polymerase chain reaction (RT-PCR) showed that GM-CSF enhances mRNA expression of the interleukin-6, but does not influence the leukemia inhibitory factor (LIF) receptor mRNA expression in blastocyst stage parthenotes. These results suggest that GM-CSF may enhance the viability of porcine embryos developing in vitro in a defined culture medium.

요 약 GM-CSF는 중요한 조혈모세포 성장인자로서 면역요법에서 중요한 기능을 한다. 본 연구의 목적은 GM-CSF가 돼지 처녀생식배아의 발달과 세포 수 및 착상관련 유전자의 발현에 관한 영향을 평가하는 것이다. 본 연구에서 돼지 처녀 활성화 배아는 GM-CSF 가 $5,10,20 \mathrm{ng} / \mathrm{ml}$ 존재 하에서 7일 동안 배양하여 배 반포의 형성율과 전 세포 수 그리고 유전자 발현을 평가하였다. 그 결과 단백질이 없는 배양액에 $20 \mathrm{ng} / \mathrm{ml}$ 의 GM-CSF를 첨가 하였을 때 배 반포의 형성 율이 유의적으로 증가 하였으며 배반포의 세포 수 또한 GM-CSF 를 첨가한 배양액에서 증가 하였다. GM-CSF는 처녀생식 배 반포에서 interleukin-6의 mRNA 발현을 증가 시켰으나, LIF 수용체 mRNA 발현에는 영향을 주지 않는다는 것을 real time RT-PCR 로 밝혀내었다. 이 결과로 $\mathrm{GM}-\mathrm{CSF}$ 성분이 확인된 배양액에서 돼지 배아의 체외 발달 과 생존력을 강화 시켰음을 시사하고 있다.
\end{abstract}

Key words : Porcine parthenotes Development, GM-CSF, Gene expression, RT-PCR

\section{Introduction}

Interest in the use of embryo manipulation techniques in pig breeding programs and biotechnological research has stimulated efforts to utilize the ovaries of slaughtered animals as an alternative source of pig embryos. Serveral investigators have produced live piglet using in vitro matured (IVM) oocytes after SCNT, IVF or ICSI. However, the efficiency of in vitro development of these embryos to the blastocyst stage and the birth of piglet are still poor.

\footnotetext{
This Work was supported by research grant of the Hyejeon College in 2014.

${ }^{*}$ Corresponding Author : Jae-Dal Lee(Hyejeon College.)

Tel: +82-11-484-2284 email: jdlee@hj.ac.kr

Received November 13, 2014 Revised December 5, 2014

Accepted January 8, 2015
} 
Granulocyte-macrophage colony-stimulating factor (GM-CSF) is an important hematopoietic growth factor and immune modulator. GM-CSF also has profound effects on the functional activities of various circulating leukocytes. It is produced by a variety of cell types including T cells [1], macrophages, endothelial cells and fibroblasts upon receiving immune stimuli[2]. Recent years, GM-CSF has been implicated in the regulation of pre-implantation embryo development across several species. In vitro, exposure of artificially produced cow embryos to GM-CSF improves blastocyst development [3]. Exposure of ovine embryos to GM-CSF in vitro increases their implantation potential through enhanced expression of the anti-luteotropic signal, interferon-t, $(\mathrm{IFN}-\mathrm{t})$ in trophectoderm cells [4]. GM-CSF also been secreted in mice reproductive tract and regulated by ovarian steroid hormones. The expressions of GM-CSF is further induced in early pregnancy by factors in seminal fluid .Researchers also found that GM-CSF play some important roles in embryos development and pregnant in human $[5,6]$. in vitro conditions for human embryo culture generally considered to be suboptimal, and embryo development is often arrested or delayed [7]

However, it remains to be elucidated whether GM-CSF can stimulate pig embryo development in vitro.

Proteins, such as those contained within serum and bovine serum albumin (BSA), are common constituents of culture mediums employed for pre-implantation mammalian embryo studies. Because there are many unidentified factors in serum and BSA, they may interact with other components to mask their effects in the medium. Recently, Wang and Day [8] reported that porcine embryos produced in vitro could develop to the blastocyst stage in a defined medium. Use of a chemically defined medium is, therefore, important for evaluating components that may affect embryo development.

Although the factors that regulate blastocyst implantation are incompletely understood, studies have strongly suggested a critical role for specific autocrine and paracrine factors that are produced from embryos, including interleukins (IL) and leukemia-inhibiting factors (LIF)[9]. Because of GM-CSF secretion from the endometrium correlates with embryo development, exposure of porcine embryo to GM-CSF may enhance mRNA expression of implantation-related genes [10].

In this study, we examined the effect of GM-CSF on in vitro development of porcine diploid parthenotes and cell numbers in the absence of BSA. We also determined the effect of GM-CSF on the expression of implantation-related genes such as LIF receptor (LIF-r) and $\mathbb{I L}-6$ in porcine parthenotes by real time reverse transcription polymerase chain reaction.

\section{Materials and Methods}

\subsection{In Vitro Maturation and Activation}

Prepubertal porcine ovaries were collected from a local slaughterhouse and transported to the laboratory at $25{ }^{\circ} \mathrm{C}$ in Dulbecco's phosphate buffered saline supplemented with $5.54 \mathrm{mM}$ D-glucose, $0.33 \mathrm{mM}$ sodium pyruvate, $75 \mathrm{mg} / \mathrm{ml}$ potassium penicillin $\mathrm{G}$ and $50 \mathrm{mg} / \mathrm{ml}$ streptomycin sulphate (mDPBS). Cumulus-oocyte complexes (COC) were aspirated from follicles 3 to $6 \mathrm{~mm}$ in diameter with an 18-gauge needle into a disposable $10 \mathrm{ml}$ syringe. The $\mathrm{COC}$ were washed 3 times with Hepes-buffered Tyrodes medium containing $0.1 \quad \% \quad(\mathrm{w} / \mathrm{v})$ polyvinyl alcohol (Hepes-TL-PVA). Each group of 50 COC was matured in $500 \mathrm{ml}$ tissue culture medium (TCM)-199 supplemented with $0.57 \mathrm{mM}$ cysteine (Sigma, St Louis, MO, USA), $10 \mathrm{ng} / \mathrm{ml}$ epidermal growth factor (Sigma), $10 \mathrm{IU} / \mathrm{ml}$ PMSG (Sigma) and $10 \mathrm{IU} / \mathrm{ml}$ hCG (Sigma) under paraffin oil at $39{ }^{\circ} \mathrm{C}$ for $44 \mathrm{~h}$. Following maturation, cumulus cells were removed by pipetting in the presence of $1 \mathrm{mg} / \mathrm{ml}$ hyaluronidase for 2-3 min. For parthenogenetic activation, denuded oocytes were exposed to $20 \mathrm{mM}$ ionomycin calcium salt (Sigma) for $4 \mathrm{~min}$ at $39{ }^{\circ} \mathrm{C}$. The oocytes were cultured for a further $3 \mathrm{~h}$ in North Carolina State University (NCSU) 37 medium containing $7.5 \mathrm{mg} / \mathrm{ml}$ cytochalasin $\mathrm{B}(\mathrm{CB}$; Sigma) 


\subsection{Real Time Reverse Transcription} Polymerase Chain Reaction (RT-PCR)

Embryos were cultured in vitro and harvested at the blastocyst stage on day 7. 10 embryos were washed in $\mathrm{Ca}^{2+}-$ and $\mathrm{Mg}^{2+}$-freephosphate-buffered saline(PBS), snap frozen in liquid nitrogen, and stored at $-70{ }^{\circ} \mathrm{C}$. Messenger RNA was extracted by using the Dynabeads mRNA Direct Kit (Dynal Asa, Oslo, Norway) according to the manufacturer's instructions. Initially, standard cDNA synthesis was achieved by reverse transcription of RNA using the Oligo(dT) $)_{12-18}$ primer and super-script reverse transcriptase (Invitrogen Co., Grand Island, NY). Real time RT-PCR was performed using the three primer sets (GAPDH, AF017079, forward primer: GGGCATGAACCATGAGAAGT, reverse primer: AAGCAGGGATGATGTTCTGG; IL-6, M80258, forward primer: ACAAAGCCACCACCCCTAAC, reverse primer: ACATTATCCGAATGGCCCTC; LIF-r, U91518, forward primer: ATACAGACGGAGGAATGGGC, reverse primer: CCACTCCAACAATGACTGCC) by DNA Engine OPTICOJ 2 (MJ research, USA). The relative quantification of gene expression was analyzed using the 2-ddCt method. In all experiments, GAPDH mRNA was employed as an internal standard for the analysis of relative transcript levels

\subsection{Cell Counting}

Blastocysts were fixed in $3.7 \%$ formalin solution for a minimum of $20 \mathrm{~min}$ at room temperature. They were then placed on slides with a drop of mounting medium consisting of glycerol : PBS (3:1) containing $2.5 \mathrm{mg} / \mathrm{ml}$ sodium azide and $2.5 \mathrm{mg} / \mathrm{ml}$ Hoechst 33342 (Sigma). A coverslip was placed on top, and the edge was sealed with nail polish. Total cell numbers in stained blastocysts were counted under an Olympus fluorescence microscope.

\subsection{Experimental Design and Embryo Culture}

Experiment 1 examined the effect of GM-CSF (Sigma, G-0282) on porcine parthenotes when added to their culture medium in the absence of BSA. Parthenogenetically-activated oocytes were washed three times in NCSU 37 medium without BSA and then randomly cultured in the same medium containing 0,5 , 10, or $20 \mathrm{ng} / \mathrm{ml}$ GM-CSF. The embryos were cultured for 7 days at $39^{\circ} \mathrm{C}, 5 \% \mathrm{CO}_{2}$ in air. Percentage of blastocysts was evaluated.

Experiment 2 was conducted to determine the effect of GM-CSF on the total cell numbers in blastocyst, embryos were harvested at day 7 and cell numbers were counted.

Experiment 3 evaluated $\mathrm{IL}-6$ and $\mathrm{LIF}-\mathrm{r}$ gene expression in porcine parthenotes. Presumptive diploid parthenotes were collected at the blastocyst stage on day 7 , then washed in PBS and stored at $-70^{\circ} \mathrm{C}$ until RT-PCR analysis.

\subsection{Statistical Analysis}

The general linear models (GLM) procedure in Statistical Analysis System (SAS User's guide, 1985, Statistical Analysis System, Inc., Cary, NC, USA) was used to analyze developmental rates. Significant differences were determined using Tukey's Multiple Range Test [11] with $\mathrm{p}$ values of $<0.05$ being considered significant. A paired student t-test was used to compare relative gene expression.

\section{Results}

\subsection{Effect of GM-CSF on the developmental rate}

To investigated wheth GM-CSF could increase the development of porcine parhenogenatic embryos , 5 and 10ng/ml GM-CSF did not affect both cleavage and blastocyst formation in the absence of protein. Addition of $20 \mathrm{ng} / \mathrm{ml}$ GM-CSF to BSA-free NCSU 37 medium also did not increase cleavage rates, but significantly increased the blastocoel formation(26.14 $\pm 0.3 \%$ )of cell embryo developing in vitro compared with control ( $p$ $<0.05$, ). 


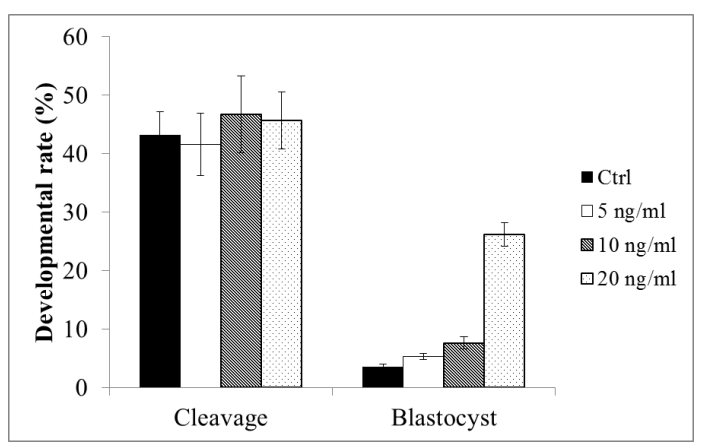

[Fig. 1] Development of parthenogenetically activated porcine embryos following different concentration of GM-CSF treatment.

Data are expressed as the percentage \pm SEM of three independent repetitions of the experiments. “*”, $\mathrm{p}<0.05$.

\subsection{Effect of GM-CSF on the cell numbers}

To test if GM-CSF affect cell numbers, total nuclei numbers were analysed by Hoechst staining in porcine blastocyst-stage parthenote, as shown in Figure2, cell number in $20 \mathrm{ng} / \mathrm{ml}$ GM-CSF treatment group(43.51 $\pm 3.6)$ cell number was significantly $(\mathrm{p}<0.05)$ increased than control(30.68 \pm 5.51$)$ but 5 and $10 \mathrm{ng} / \mathrm{ml}$ GM-CSF did not affect it.

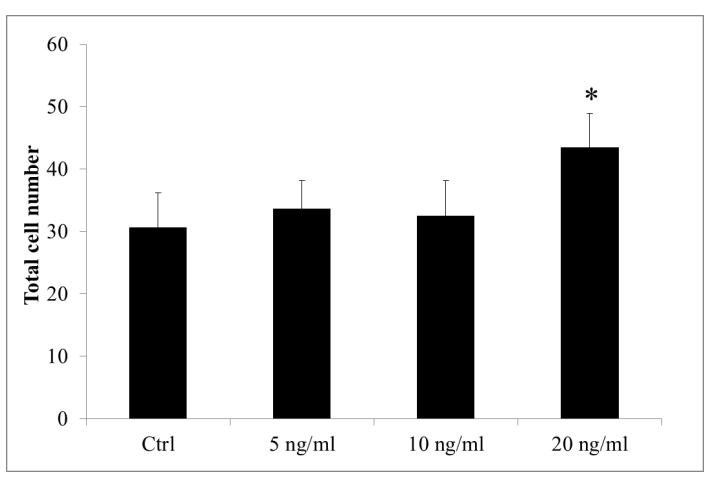

[Fig. 2] Total cell number of parthenogenetically activated porcine embryos following different concentration of GM-CSF treatment.

Data are expressed as the Mean \pm SEM of three independent repetitions of the experiments. “*”, $\mathrm{p}<0.05$.

\subsection{Effect of GM-CSF on the gene expression}

To investigate whether GM-CSF modulates mRNA expression of implantation-related genes in porcine embryos developing in vitro, mRNA prepared from 10 blastocysts was reverse transcribed and analyzed by PCR with primers specific for $\mathrm{IL}-6$ and $\mathrm{LIF}-\mathrm{r}$ cDNAs.

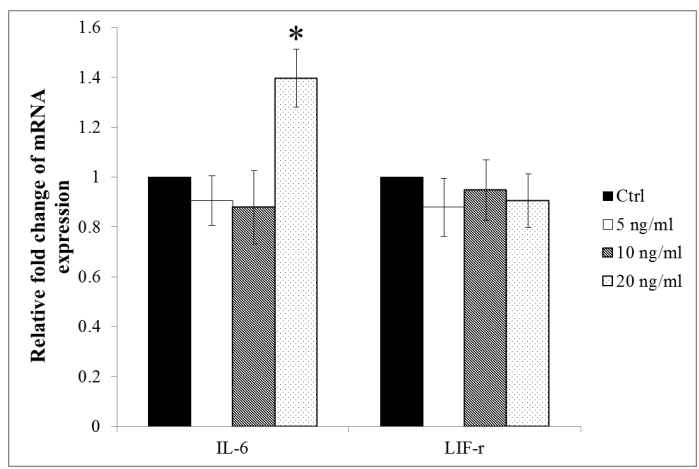

[Fig. 3] Relative mRNA expression of IL-6 and LIF-r in blastocysts treated with different concentration of GM-CSF.

Data are expressed as the Mean \pm SEM of three independent repetitions of the experiments. “*”, $\mathrm{p}<0.05$.

In the absence of BSA, mRNA expression of IL-6 was significantly $(\mathrm{p}<0.05)$ increased about 1.4 fold in the $20 \mathrm{ng} / \mathrm{ml} \mathrm{GM}-\mathrm{CSF}$ group than other groups and control, but LIF-r mRNA was no differences among the groups

\section{Discussion}

GM-CSF is a multifunctional cytokine originally identified as a regulator of the proliferation and differentiation in myeloid hemopoietic cells [12]. During early pregnancy, GM-CSF acts as a potentially important intracellular regulator of endometrial and embryonic function. In the present study, GM-CSF did not enhance cleavage [9], but accelerate blastocoel formation, consistent with results of the bovine, human and mice $[3,13]$. And, the cell number of blastocysts 
that underwent development in the presence of GM-CSF was higher than that of control.

Because of in the early stage of cleavage, embryos maternal mRNA for protein synthesis, compared with the resilts in other species, it revealed that GM-CSF might regulate mRNA synthesis of some key gene involved in blastocyst formation and cell division after genomic activation, such as E-cadherin or $\mathrm{Na} / \mathrm{K}$ ATPase [14].

Clearly, pre-implantation embryos are dependent on reproductive track-derived regulatory mechanisms. A variety of growth factors and regulatory molecules in the uterine environment are known to affect development of pre-implantation embryos. In cattle, exposure of embryos to a uterine environment is required for interferon- $t$ secretion, which is important in regulating implantation [15]. In the present study, we examined the mRNA expression of $\mathrm{IL}-6$ and $\mathrm{LIF}-\mathrm{r}$ in blastocysts developing in vitro in the absence of GM-CSF. These genes have been demonstrated to be involved in implantation processes. Interleukin 6 has been shown to have a potentially important function in blastocyst development and implantation in mouse embryos [16]. LIF transcrips have been detected in the preimplantation stage blastocyst in the mouse, and LIF receptors have been found on the 4-day-old mouse embryo [17]. Real time RT-PCR revealed that expression of $\mathbb{I L}-6$ was increased in blastocyst cultured in the presence of GM-CSF. Previously, it was shown that its expression is essential for implantation. Thus, up-regulation of IL-6 in porcine embryos cultured in the absence of FGM-CS possibly results in enhanced viability of embryos for implantation.

\section{References}

[1] van Montfort, T., et al., A chimeric HIV-1 envelope glycoprotein trimer with an embedded granulocytemacrophage colony-stimulating factor (GM-CSF) domain induces enhanced antibody and T cell responses. J Biol Chem, 286(25): p. 2250-61. 2011
DOI: http://dx.doi.org/10.1074/jbc.M111.229625

[2] Shi, Y., et al., Granulocyte-macrophage colony-stimulating factor (GM-CSF) and T-cell responses: what we do and don't know. Cell Res, 16(2): p. 126-33. 2006.

DOI: http://dx.doi.org/10.1038/si.cr.7310017

[3] de Moraes, A.A. and P.J. Hansen, Granulocyte-macrophage colony-stimulating factor promotes development of in vitro produced bovine embryos. Biol Reprod, 57(5): p. 1060-5. 1997

DOI: http://dx.doi.org/10.1095/biolreprod57.5.1060

[4] Imakawa, K., et al., A novel role for GM-CSF: enhancement of pregnancy specific interferon production, ovine trophoblast protein-1. Endocrinology, 132(4): p. 1869-71. 1993

DOI: http://dx.doi.org/10.1095/biolreprod57.5.1060

[5] Robertson, S.A., GM-CSF regulation of embryo development and pregnancy. Cytokine Growth Factor Rev, 18 (3-4): p. 287-98. 2007

DOI: http://dx.doi.org/10.1016/j.cytogfr.2007.04.008

[6] Ziebe, S., et al., A randomized clinical trial to evaluate the effect of granulocyte-macrophage colony-stimulating factor (GM-CSF) in embryo culture medium for in vitro fertilization. Fertil Steril, 99 (6): p. 1600-9, 2013

DOI: http://dx.doi.org/10.1016/j.fertnstert.2012.12.043

[7] Hardy,k.,A.H. Handyside, and R.M. Winston, The human blastocyst; cell number, deat and allocation during late preimplantation development in vitro. dev, 107(3): p597-604.1989

[8] Wang, W.H. and B.N. Day, Development of porcine embryos produced by IVM/IVF in a medium with or without protein supplementation: effects of extracellular glutathione. Zygote, 10(2): p. 109-15, 2002 DOI: http://dx.doi.org/10.1017/S0967199402002150

[9] Stewart, C.L. and E.B. Cullinan, Preimplantation development of the mammalian embryo and its regulation by growth factors. Dev Genet, 21(1): p. 91-101, 1997 DOI: http://dx.doi.org/10.1002/(SICI)1520-6408(1997)21:1 $\leq 91:$ AID-DVG11>3.0.CO;2-D

[10] Kim DH, et al., Effect of GM-CSF on the embryonic development and the expression of implantation related genes of mouse embryos. . Kor J Fertil Steril, . 2002 (29): p. 83-90, 2002

[11] Steel, R.G.D. and J.H. Torrie, Principles and Procedures of Statistics, NY: Mcgraw Hill Book co 2000

[12] Ruef, C .and D .L. Coleman, colony - stimulating factor: pleiotropic cytokine with potential clinical usefulness. Rev Infect Dis, 12(1): p. 41-62,2006 
DOI: http://dx.doi.org/10.1093/clinids/12.1.41

[13] Elaimi, A., et al., The effect of GM-CSF on development and aneuploidy in murine blastocysts. Hum Reprod, 27(6):

p. $1590-5,2012$

DOI: http://dx.doi.org/10.1093/humrep/des108

[14] Watson, A.J., The cell biology of blastocyst development.

Mol Reprod Dev,. 33 (4): p. 492-504,2006

DOI: http://dx.doi.org/10.1002/mrd.1080330417

[15] Hernandez-Ledezma, J.J., et al., Expression of bovine trophoblast interferon in conceptuses derived by in vitro techniques. Biol Reprod, 47(3): p. 374-80,1992

DOI: http://dx.doi.org/10.1095/biolreprod47.3.374

[16] Desai, N., et al., Evaluation of the effect of interleukin-6 and human extracellullar matrix on embryonic development. Hum Reprod, 14(6): p. 1588-92,1999

DOI: http://dx.doi.org/10.1093/humrep/14.6.1588

[17] Conquet, F. and P. Brulet, Developmental expression of myeloid leukemia inhibitory factor gene in preimplantation blastocysts and in extraembryonic tissue of mouse embryos. Mol Cell Biol, 10(7): p. 3801-5,2007

Jae-Dal Lee

[Regular member]

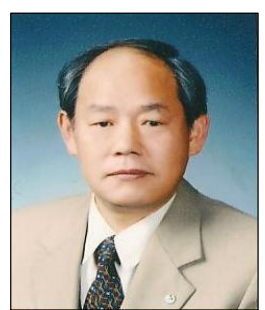

- Feb. 1977 : ChungNam National Univ., Dept. of Textile Engineering

- Feb. 1990 : ChungNam National Univ., Dept. of Textile Engineering, MS

- Feb. 1999 : ChungNam National Univ., Dept. of Textile Engineering, $\mathrm{PhD}$

- Aug. 2007 : ChungBuk National Univ., Dept. of Animal Science Graduate, MS

- Mar. 1995 current : Hyejeon College, Dept. of Pet Care, Professor

$<$ Research Interests $>$

Animal Reproductive Physiology 